\title{
FIRST DOCUMENTED RECORD OF IMPERIAL BLACKFISH, SCHEDOPHILUS OVALIS (ACTINOPTERYGII: PERCIFORMES: CENTROLOPHIDAE), IN THE AEGEAN GREEK WATERS
}

\author{
Maria CORSINI-FOKA $^{1 *}$ and Alexandros FRANTZIS ${ }^{2}$ \\ ${ }^{1}$ Hydrobiological Station of Rhodes/Hellenic Centre for Marine Research, Rhodes, Greece \\ ${ }^{2}$ Pelagos Cetacean Research Institute, Vouliagmeni, Greece
}

Corsini-Foka M., Frantzis A. 2009. First documented record of imperial blackfish, Schedophilus ovalis (Actinopterygii: Perciformes: Centrolophidae), in the Aegean Greek waters. Acta Ichthyol. Piscat. 39 (1): $47-49$.

\begin{abstract}
The first record of imperial blackfish, Schedophilus ovalis (Cuvier, 1833), in the Greek waters of the Aegean Sea is herewith documented. This record increases the knowledge on the richness of the Hellenic marine ichthyofauna and may suggest an expansion of the geographical distribution of the species from the southern Levantine waters to northern areas.
\end{abstract}

Keywords: Schedophilus ovalis, imperial blackfish, Centrolophidae, rare fish, Mediterranean, Aegean Sea, Greece

The family Centrolophidae includes 27 species distributed worldwide in all tropical and temperate seas (Froese and Pauly 2008). They are medium-sized to large pelagic deep-water fishes, juvenile and young adults commonly associated with animate and inanimate floating objects (Haedrich 1986a). Four species occur in the Mediterranean, some of which are considered commercially important (Bauchot 1987): Centrolophus niger (Gmelin, 1788); Hyperoglyphe perciformis (Mitchill, 1815); Schedophilus medusophagus Cocco, 1839; and Schedophilus ovalis (Cuvier, 1833). Among these species, only
Centrolophus niger is known to occur in the Greek waters of the Aegean Sea (Bauchot 1987, Papaconstantinou 1988).

On 15 May 2008, a specimen of Schedophilus ovalis (Fig. 1), was caught with hand-line, between the Aegean islands of Chios and Ikaria $\left(\sim\right.$ lat $37^{\circ} 55^{\prime} 00^{\prime \prime} \mathrm{N}$, long $\left.26^{\circ} 00^{\prime} 00^{\prime \prime} \mathrm{E}\right)$. According to the fisherman observations, the fish belonged to a school of 8-10 individuals, with a weight assessed as fitting into the range of $1000-2500 \mathrm{~g}$. The school swam for about two hours, near the surface, 1-8 $\mathrm{m}$, under the fishing boat which was performing its

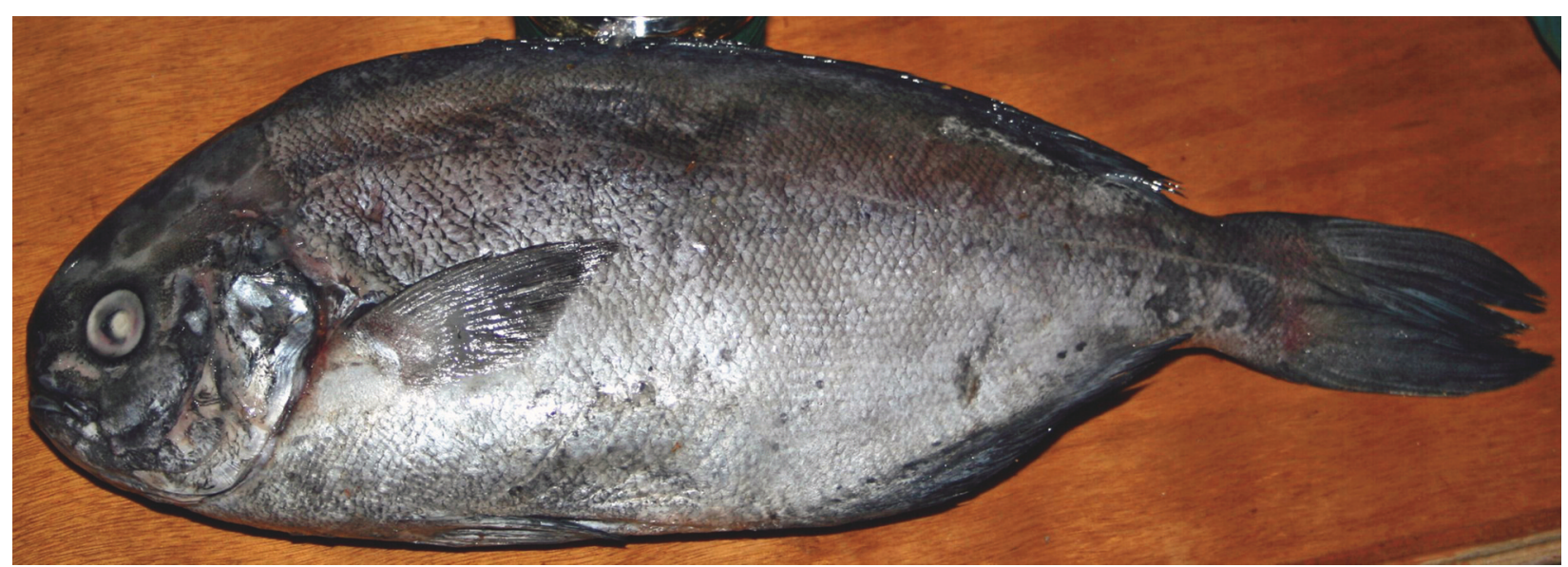

Fig. 1. The freshly caught specimen of Schedophilus ovalis from the Aegean Sea (Photo: S. Kavvadas)

\footnotetext{
* Correspondence: Dr. Maria Corsini-Foka, Hydrobiological Station of Rhodes/Hellenic Centre for Marine Research. Cos Street, 85100 Rhodes, Greece, phone: (+30) 22410 27308, fax: (+30) 22410 78321, e-mail: mcorsini@hcmr.gr
} 
activities at the depth of $250 \mathrm{~m}$. The presence of the imperial blackfish in the same area was confirmed by observation of other schools during June and July.

The species was identified according to Bauchot (1987) and Haedrich (1986b). Morphometric measurements were carried out on the defrosted specimen to the nearest $0.1 \mathrm{~mm}$ by a calliper, and meristic counts were made under the reflected light of a stereomicroscope. The sample, fixed in $70 \%$ ethanol, has been preserved at the Hydrobiological Station of Rhodes collection (Catalogue number HSR-F43).

The specimen, $397 \mathrm{~mm}$ in total length and $1150 \mathrm{~g}$ in weight, presented the following meristic characters: dorsal fin rays VII +32 , anal fin rays III +21 , pectoral fin rays 21 , ventral fin rays $I+5$, caudal fin rays 23 . Gill rakers on first arch were $16+1+6$. The morphometric data gave the following ratios, as percent of standard length (SL) or head length (HL): maximum body depth 40.3, head length 25.8, predorsal length 20.3, preventral length 27 , preanal length 51.6 all in SL; caudal peduncle length 60.8 , eye diameter 21.3, preorbital distance 30 , postorbital 57 , all in HL (Table 1). The defrosted specimen was dark greenish-black dorsally and silvery ventrally.

The imperial blackfish is a subtropical species, showing generally a vertical age distribution: the adults live near the bottom in deep waters, young specimens are mesopelagic over the continental shelf, while juveniles are epipelagic and associate with floating jellyfish, including Physalia (cf. Haedrich 1986b, Follesa et al. 2006, Golani et al. 2006, Froese and Pauly 2008). It reaches $80-100 \mathrm{~cm}$ of total length and it feeds on tunicates and other inverte- brates (Golani et al. 2006). S. ovalis is distributed in the Eastern Atlantic from Spain to southward, also Western Central Atlantic, around oceanic islands, and it occurs furthermore throughout most of the Mediterranean, where it is considered rare (Haedrich 1986b, Bauchot 1987, Massutí et al. 1999, Golani et al. 2006). Concerning recent records in the Mediterranean waters, the occurrence of this rare species has been reported for the French coasts (Francour and Javel 2003), the south-eastern Adriatic Sea (Dulčić et al. 2003, 2004), the waters all around Sardinia (Follesa et al. 2006) and the central Tyrrhenian Sea (Psomadakis et al. 2006). In the Aegean Sea, S. ovalis has been recorded only at Izmir, along the Anatolian coasts of Turkey (Bilecenoglu et al. 2002). Listed among the rare fish of Greece (Papaconstantinou 1990a), the occurrence of the imperial blackfish in Greek waters was known previously only along the south coasts of Crete and the Hellenic Arc more generally (Bauchot 1987, Papaconstantinou 1988).

The finding of $S$. ovalis described in this paper represents the first documented record for the Aegean Hellenic waters and the second one for the whole Aegean Sea. The size and the epipelagic behaviour of specimens observed in the area between Chios and Ikaria Islands show that they were young individuals (Orsi-Relini et al. 1990, Francour and Javel 2003). Although the existence of a previously unknown and undetected population in the specific area is not to be undervalued, the closeness in time and place of the records of $S$. ovalis in the Turkish and Greek waters could be perhaps an indication of a recent expansion of the geographical distribution of this

Morphometric characters of the Schedophilus ovalis specimen from the Aegean Sea

Table 1

\begin{tabular}{lc}
\hline Character & Value [mm] \\
\hline Total length & 397.0 \\
Fork length & 374.0 \\
Standard length & 335.0 \\
Max. body depth & 135.0 \\
Min. body depth & 135.0 \\
Caudal peduncle length & 52.5 \\
Head length & 86.3 \\
Eye diameter & 18.4 \\
Preorbital distance & 25.0 \\
Postorbital distance & 48.9 \\
Interorbital distance & 31.7 \\
Dorsal fin base length & 207.0 \\
Anal fin base length & 105.0 \\
Pectoral fin length & 74.0 \\
Ventral fin length & 56.8 \\
Distance between pectoral and ventral fin origin & 178.2 \\
Distance between ventral and anal fin origin & 81.5 \\
Predorsal length & 68.0 \\
Preventral length & 90.0 \\
Preanal length & 173.0 \\
\hline
\end{tabular}


rare species from the southern waters of the Levantine basin to the eastern Aegean Sea, at the limits between its central and north part, as defined by Papaconstantinou (1990b) and Sakellariou and Alexandri (2007). A continuous expansion of its distribution has been already documented in the Western Mediterranean during the last decade (Follesa et al. 2006). The hypothesis of the distribution extension of $S$. ovalis could be supported by colonization of vacant niches in the new area, useful for the species, but also by the warming of the Aegean Sea waters, as it has been assumed to explain the increasing occurrence of the imperial blackfish in other regions of the Mediterranean Basin (Francour and Javel 2003, Dulčić et al. 2004). The range extension of $S$. ovalis from southern waters to the Aegean Sea could be considered also a phenomenon similar and parallel to that concerning the colonization and/or invasion of the Aegean waters by alien IndoPacific tropical fishes observed in the last years (CorsiniFoka and Economidis 2007). Finally, although a bloom of the jellyfish, Pelagia noctiluca, population has been observed for a prolonged three years period (2004 to 2006), in the Aegean Sea, in particular in its south-eastern corner, an association of the occurrence of $S$. ovalis described here to jellyfish appears in this case hazardous, since no data on the actual situation are available.

\section{AKNOWLEDGEMENTS}

Authors are grateful to Mr. Giorgos Galatoulas and Mr. Stelios Kavvadas for providing the specimen of Schedophiolus ovalis and information on its capture.

\section{REFERENCES}

Bauchot M.-L. 1987. Poissons osseux. Pp. 891-1422. In: Fischer W., Bauchot M.-L., Schneider M. (eds.) Fiches FAO d'identification des espèces pour les besoins de la pêches. (Révision 1). Méditerranée et Mer Noire. Zone de pêche 37. Vol. 2, Vertébrés. FAO, Rome.

Bilecenoglu M., Taskavak E., Mater S., Kaya M. 2002. Checklist of the marine fishes of Turkey. Zootaxa 113: 1-194.

Corsini-Foka M., Economidis P.S. 2007. Allochthonous and vagrant ichthyofauna in Hellenic marine and estuarine waters. Mediterranean Marine Science 8 (1): 67-89.

Dulčić J., Onofri V., Jardas I., Pallaoro A., Soldo A., Glamuzina B. 2004. Some new data on the occurrence of Schedophilus ovalis (Cuvier, 1833) (Pisces: Centrolophidae) in the eastern Adriatic. Rapports et Proces Verbaux des réunions-Commission Internationale pour l'Exploration Scientifique de la mer Méditerranée 37: 348.

Dulčić J., Pallaoro A., Onofri V., Lučić D., Jardas I. 2003. New additional records if imperial blackfish, Schedophilus ovalis (Cuvier, 1833), white trevally, Pseudocaranx dentex
(Bloch \& Schneider, 1801), and Atlantic pomfret, Brama brama (Bonnaterre, 1788), in the Eastern Adriatic. Annales, Series Historia Naturalis 13 (2): 149-154.

Follesa M.C., Pais A., Cau A. 2006. Recent records of Schedophilus ovalis (Osteichthyes, Centrolophidae) from Sardinian waters (Central-Western Mediterranean). Biologia Marina Mediterranea 13: 861-865.

Francour P., Javel F. 2003. Recent occurrences of young Schedophilus ovalis (Centrolophidae) along French Mediterranean coasts. Cybium 27 (1): 57-58.

Froese R., Pauly D. (eds.) 2008. FishBase. www.fishbase.org version $(4 / 2008)$.

Golani D., Öztürk B., Basusta N. 2006. Fishes of the eastern Mediterranean. Turkish Marine Research Foundation, Istanbul.

Haedrich R.L. 1986a. Stromateidae. Pp. 842-846. In: Smith M.M., Heemstra P.C. (eds.) Smith's sea fishes. Springler-Verlag, Berlin.

Haedrich R.L. 1986b. Centrolophidae. Pp. 177-1182. In: Whitehead P. J. P., Bauchot M.-L., Hureau J.-C., Nielsen J., Tortonese E. (eds.) Fishes of the North-eastern Atlantic and the Mediterranean. Vol. 3. UNESCO, Paris.

Massutí E., Morales-Nin B., Deudero S. 1999. Fish fauna associated with floating objects sampled by experimental and commercial purse nets. Scientia Marina 63 (3-4): 219-227.

Orsi-Relini L., Fida B., Relini M. 1990. Notes about Schedophilus ovalis (Osteichthyes, Centrolophidae) in the Ligurian sea. Rapports et Proces Verbaux des réunionsCommission Internationale pour l'Exploration Scientifique de la mer Méditerranée 32: 272.

Papaconstantinou C. 1988. Check-list of marine fishes of Greece. FAUNA GRAECIAE IV. National Center for Marine Research, Hellenic Zoological Society, Athens.

Papaconstantinou C. 1990a. Some rare mesopelagic and bathyal fish caught in the Greek seas. Thalassographica 13: 35-39.

Papaconstantinou C. 1990b. The spreading of Lessepsian fish migrant into the Aegean Sea (Greece). Scientia Marina 54 (4): 313-316.

Psomadakis P.N., Scacco U., Vacchi M. 2006. Recent findings of some uncommon fishes from the central Tyrrhenian Sea. Cybium 30 (4): 297-304.

Sakellariou D., Alexandri M. 2007. Geomorphology of the Hellenic sea-floor. Pp. 17-23. In: Papaconstantinou C., Zenetos A., Vassilopoulou V., Tserpes G. (eds.) State of Hellenic Fisheries (SoHelFi). HCMR publications, Athens.

Received: 31 July 2008

Accepted: 26 January 2009

Published electronically: 20 May 2009 